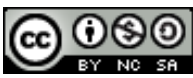

https://doi.org/10.31743/abmk.12601

ANNA WIŚNICKA* - WARSZAWA

\title{
WYBRANE ASPEKTY MINIMALISTYCZNYCH REARANŻACJI WNĘTRZ KOŚCIELNYCH PO ROKU 2000
}

\begin{abstract}
Streszczenie
W artykule przybliżono tematykę minimalistycznych rewitalizacji wnętrz sakralnych Kościoła rzymskokatolickiego w oparciu o selekcję reprezentatywnych przykładów, zdywersyfikowanych pod względem geograficznym i kulturowym. Wychodząc od założeń Soboru Watykańskiego II oraz zmian artystycznych i społeczno-kulturowych, które zaobserwować można już w XIX wie$\mathrm{ku}$, artykuł analizuje czynniki, które doprowadziły do skrajnej redukcji formalnej w wystroju kościołów. Poza oczywistą kwestią, jaką jest architektura wnętrz, podjęty zostaje namysł nad sposobem eksponowania sztuki, którą stanową zarówno element kultowy, jak i estetyczny. Wzięto również pod uwagę czynniki prawne, aspekty liturgiczne oraz psychologiczne. Do analizy problemu wykorzystano realizacje i projekty z kręgu architektury europejskiej.

Słowa kluczowe: architektura wnętrz; estetyka; design; sztuka Kościoła rzymskokatolickiego; wnętrze sakralne; architektura kościelna; minimalizm
\end{abstract}

$* * * * *$

Wnętrza kościelne to miejsca szczególne, które w założeniu winny łączyć funkcje kultowe z estetyczną stroną wizualną. Choć na przestrzeni wieków wygląd świątyń ulegał znacznej ewolucji stylowej, wszechobecny minimalizm wciąż nie stanowi pierwszej konotacji, która przychodzi na myśl w kontekście sfery sacrum Kościoła rzymskokatolickiego. Od czasów Soboru Trydenckiego (1545-1563) architektura, wnętrza sakralne i znajdujące się w nich dzieła sztuki stanowiły integralną część narracji wokół kwestii liturgii. Postanowienia soborowe bardzo jasno opowiadają się za wartością anturażu artystycznego, będącego wizualnym dopełnieniem nabożeństwa: ,gdyby ktoś mówił, że obrzędy, szaty i znaki zewnętrzne,

*Anna Wiśnicka - dr historii sztuki, adiunkt w Instytucie Kulturoznawstwa, Uniwersytet Kardynała Stefana Wyszyńskiego w Warszawie

e-mail: a.wisnicka@uksw.edu.pl

https://orcid.org/0000-0002-6821-529X 
których używa przy sprawowaniu mszy Kościół katolicki, są bardziej podnietą do bezbożności niż pełnieniem pobożności - niech będzie wyklęty"”.

Szczególnie przedstawienia związane bezpośrednio z postaciami otoczonymi kultem powinny znajdować swoje miejsce w świątyniach, o czym świadczy fragment: obrazy Chrystusa, Bożej Rodzicielki oraz innych świętych należy posiadać i zachowywać zwłaszcza w świątyniach, i oddawać im należną cześć i uszanowanie, nie dlatego by wierzono, że tkwi w nich jakieś bóstwo czy moc, ze względu na które miałyby być czczone; lub że można ich o coś prosić; lub że należy pokładać nadzieję w obrazach, jak niegdyś czynili poganie, którzy swą nadzieję pokładali w bożkach, ale dlatego, że okazywany im honor odnosi się do wzoru, który przedstawiają. W ten sposób przez obrazy, gdy je całujemy, odkrywamy przed nimi głowę i klękamy, adorujemy Chrystusa i czcimy świętych, których one noszą podobizny. Zatwierdziły to sobory, zwłaszcza Sobór Nicejski II przeciwko obrazoburcom².

Rozwój sztuk po Soborze Trydenckim³ ${ }^{3}$ w szczególności rozkwit wybujałych form barokowych będących antytezą estetyki proponowanej przez rozwijający się protestantyzm, na długi czas ukształtował model wystroju wnętrz. Również daleko posunięta barokizacja dekoracji świątyń romańskich czy gotyckich doprowadziła do znaczącej przewagi tejże estetyki oraz jej ukonstytuowania się jako wiodącej tendencji ${ }^{4}$.

Należy zastanowić się, jakie czynniki miały wpływ na stopniowe odchodzenie od dawnych prawideł projektowania wnętrz sakralnych na rzecz kierunków, które dążą do coraz dalej posuniętego redukcjonizmu. Przyglądając się epoce nowoczesnej, za punkt wyjścia bez wątpienia traktować można XIX wiek - okres pluralizmu stylowego oraz nieskrępowanych poszukiwań formalnych. Czas ten, architektonicznie i wzorniczo, skupiony był na eksploracji stylów dawnych, korzystając jednocześnie z dobrodziejstw nowoczesnych technologii, które niosła za sobą industrializacja. Powstające wówczas wnętrza kościelne cechuje różnorodność rewiwalistyczna, za przykład której posłużyć mogą kościół św. Michała Archanioła w Berlinie (1851-1861) łączący elementy neoklasycyzmu i neogotyku, neoklasycystyczny kościół św. Magdaleny w Paryżu (1808-1842), neorenesansowy kościół Serca Jezusowego w Rzymie na Castro Pretorio czy eklektyczna bazylika archikatedralna św. Jana Apostoła i Ewangelisty, św. Michała Archanioła i Nie-

${ }^{1}$ Dokumenty Soborów Powszechnych. Tekst łaciński i polski, t. 4/1: (1511-1870) Lateran V, Trydent, Watykan I, oprac. A. Baron, H. Pietras SJ, Kraków 2004, s. 647.

${ }^{2}$ Tamże, s. 781-783.

${ }^{3}$ Więcej na temat istoty i roli Soboru Trydenckiego zob. J. Królikowski, Sobór Trydencki i jego inspirujace znaczenie, w: Dzieje diecezji tarnowskiej, t. 7: Synody Diecezji Tarnowskiej, red. A. Żurek, J. Soprych, Kraków 2017, s. 47-56.

${ }^{4}$ Warto nadmienić, iż pierwszy potrydencki dokument mówiący o sztuce kościelnej na ziemiach polskich wspomina również o usuwaniu z wnętrz świątyń np. wizerunków, które doprowadzić mogą do złej interpretacji dogmatów Kościoła; por. sobór zwołany przez biskupa Marcina Szyszkowskiego w 1621 r., Reformationes Generales ad clerum et populum Dioecesis Cracoviensis pertinentes ab Illustrissimo et Reverendissimo Domino D. Martino Szyszkowski (...) episcopo Cracoviensi (...) in Synodo Dioecesano sanictae et promulgatae A. D. MDCXXI, Kraków 1621, s. $152-$ 155. 
pokalanego Poczęcia Najświętszej Maryi Panny w Egerze (1831-1837). Wszystkie wspomniane budowle, zaprojektowane na wzór wielkich stylów architektonicznych wieków minionych, łączy jednak wciąż umiłowanie dekoracyjności i spójność wnętrza z architekturą. W skrajnej opozycji do mozaiki stylowej XIX wieku stał rodzący się na początku XX stulecia w Holandii i Niemczech modernizm. Redukcja formy, brak dekoracji oraz funkcjonalizm stały się na bez mała pół wieku tendencjami dominującymi w architekturze. Warto wspomnieć, że kultywowane na gruncie protestanckim idee skromności i umiaru również przyczyniły się do coraz większej popularności prostych wnętrz, szczególnie w dobie stopniowej globalizacji XX wieku oraz przenikania się trendów, co mogło prowadzić to pew-

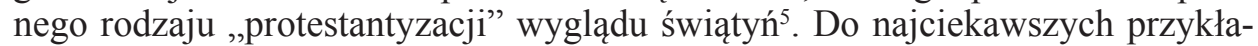
dów kościołów protestanckich, których wnętrza cechuje pierwotny lub wtórny minimalizm, należą m.in. ekspresjonistyczny Grundtvigs Kirke i St. Johannes Kirke w Kopenhadze czy St. John at Hackney w Londynie.

Mówiąc o minimalistycznych aranżacjach i re-aranżacjach wnętrz kościelnych, stosowne wydaje się przywołanie istoty terminu „minimalizm”, pierwotnie używanego w sztukach plastycznych, w odniesieniu do architektury i architektury wnętrz, co pozwoli uniknąć nieporozumień semantycznych. Minimalizm, choć często używany w literaturze, zamiast na klarownej definicji opiera się głównie na analizie bardzo zdywersyfikowanych przykładów ${ }^{6}$, które razem tworzą szeroki wachlarz pojęć. Może odnosić się do architektury, która wizualnie nie narzuca się użytkownikowi, przez modernistyczną koncepcję spłaszczenia proporcji budynków, usunięcie zbędnych elementów podziału wnętrza oraz transparentność konstrukcji, aż po skrajną redukcję elementów, które nie są uważane za niezbędne ścian działowych, ozdobnych detali, do uzyskania funkcjonalnej, lecz prostej geometrycznej formy, aż do betonowych konstrukcji w typie prac Tadao Ando, których piękno wynika ze skrajnej surowości. Biorąc pod uwagę tak szerokie spektrum użycia słowa minimalizm, w tekście potraktowany będzie jako synonim redukcjonizmu względem historycznego oryginału, niwelujący wszelkie formy dekoracyjne, które nie są niezbędne w odczuciu twórcy.

Przyglądając się współczesnym wnętrzom sakralnym Kościoła rzymskokatolickiego, warto wyróżnić na potrzeby tego opracowania ich dwa podstawowe typy - pierwotny i wtórny. Pierwotne wnętrza o charakterze minimalistycznym stanowią integralną część zamysłu architektonicznego, który od początku pomyślany był jako koncepcja redukcjonistyczna. Korespondencja bryły budynku i wnętrza wydaje się oczywista, szczególnie w kontekście budowli nowopowstałych, które nie poddawane były zmianom. Drugą grupę stanowią budowle dawne, których wnętrza, na skutek różnych czynników, zostały na nowo zaaranżowane tak, by wpisać się w panujące obecnie trendy polegające na coraz dalej posuniętej redukcji „zbędnych” elementów. Im właśnie poświęcone zostały rozważania zawarte w tekście.

\footnotetext{
${ }^{5}$ Pragnę podziękować dr Beacie Skrzydlewskiej za cenne wskazówki dotyczące dokumentów i aktów prawnych oraz mgr. Tomaszowi Pieńkowskiemu za uwagi na temat rozwoju i dywersyfikacji wnętrz kościołów protestanckich.

${ }^{6}$ F. Bertoni, Minimalist Architecture, Basel 2002, s. 7-12.

${ }^{7}$ Por. H. Obendorf, Minimalism: Designing Simplicity, London 2009, s. 54-57.
} 
Interesującym przykładem wnętrza o nowoczesnej formie jest modernizacja niemieckiego kościoła Moritzkirche w Augsburgu, przeprowadzona w latach 2008-2013 przez brytyjskie studio architektoniczne Johna Warda Pawsona, CBE. Ponad tysiącletnia budowla przetrwała liczne zniszczenia, zmiany architektoniczne oraz stylowe, które znalazły swój finał dopiero w XXI wieku. Początki kościoła św. Maurycego sięgają XI wieku, gdy został wybudowany na zlecenie biskupa augsburskiego Brunona. W XIII i XV wieku, po pożarach i zawaleniu części murów, świątynia została odbudowana oraz nieznacznie powiększona. W okresie reformacji opuszczony budynek został uszkodzony, a czasy kontrreformacji przyniosły kolejną rozbudowę bryły i barokizację kościoła według projektu Johanna Jakoba Herkomera z Füssen. Sufit ozdobiono wówczas bogatymi freskami, których autorem był Melchior Steidl, a do wnętrza wprowadzono dekoracje rzeźbiarskie w postaci grupy wolnostojących figur George'a Petersa ${ }^{8}$. W 1944 r. podczas bombardowania kościół stanął w płomieniach, a dach nawy głównej spłonął doszczętnie. Prace rekonstrukcyjne pod nadzorem Dominikusa Böhma doprowadziły do znacznego uproszczenia bryły świątyni poprzez rezygnację z odbudowy kopuły chóru.

Od 2008 r. rozpoczęto szeroko zakrojone prace mające na celu nadanie wnętrzu koherencji stylowej oraz przystosowanie go do użytkowania przez wiernych. John Pawson, zaproszony do realizacji projektu, specjalizujący się w minimalistycznych aranżacjach ${ }^{9}$, podjął decyzję o całkowitej zmianie wystroju wnętrza. $\mathrm{Z}$ uwagi na brak zachowanych w wystarczającej części elementów jednolitego stylu możliwe okazało się całkowite przearanżowanie przestrzeni, w której jedyną pozostałością po dawnym układzie było usytuowanie ołtarza oraz ław dla wiernych. Liczne przebudowy doprowadziły do utracenia przez budowlę wiodących cech stylowych, które mogłyby posłużyć za wystarczające pobudki do rekonstrukcji historycznej w oparciu o nielicznie zachowane in situ elementy oryginalne.

Według ustaleń Dokumentu z Nara o autentyzmie z 1994 r.:

znajomość, zrozumienie i interpretacja pierwotnych i późniejszych cech charakterystycznych zabytku, historycznych zmian i znaczenia jakie odgrywa, stanowią podstawę oceny autentyczności danego dobra kultury, i dotyczą w takim samym stopniu jego formy jak i materiału, z którego jest zbudowane ${ }^{10}$.

W przypadku augsburskiego kościoła zasadne wydało się odejście od rewiwalizmu na rzecz stworzenia przestrzeni, która osadzona byłaby w kontekście współczesnej estetyki.

${ }^{8}$ T. Eser, Georg Peters Bildhauerarbeiten für die Moritzkirche, w: Das ehemalige Kollegiatstift St. Moritz in Augsburg (1019-1803): Geschichte, Kultur, Kunst, red. G.M. Müller, Lindenberg 2006, s. 369-398.

${ }^{9}$ A. Morris, John Pawson: Anatomy of Minimum, London 2019, s. 194-199.

${ }^{10}$ Dokument z Nara o autentyzmie, 1994, tłum. M. Fokt-Willmann, zabytki.olsztyn.eu/filead$\mathrm{min} /$ zabytki/pdf/dokument_z_Nara_o_autentyzmie_1994_r..pdf (dostęp: 12.04.2021). 


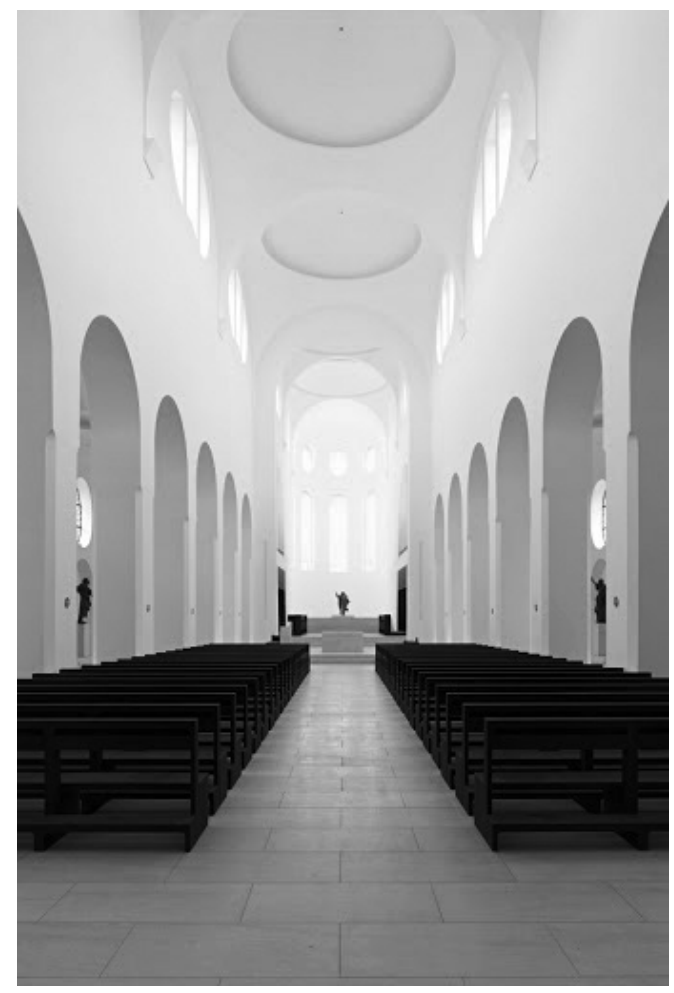

Il. 1. Kościół Moritzkirche w Augsburgu, wnętrze, projekt J. Pawson. Źródło: www.johnpawson.com/works/moritzkirche (dostęp: 12.04.2021).

Całość wnętrza pomalowano na biały kolor, a dawne ławy zastąpiono prostymi i geometrycznymi, w kolorze ciemnego drewna. Również podziały okienne oraz stolarkę drzwiową utrzymano w tej samej tonacji. Na podłodze ułożono jasne płyty kamienne o prostokątnym kształcie. Ważnym elementem, o którym należy wspomnieć, jest wygląd dwóch naw bocznych, w niszach których ustawiono na wysokich postumentach barokowe, drewniane figury G. Petersa. Białe ściany oraz duże odległości pomiędzy poszczególnymi rzeźbami sprawiają, że każda z nich jest równie mocno zaakcentowana. Ten układ przywodzi na myśl nowatorską koncepcję prezentacji sztuki, zapoczątkowaną przez dyrektora nowojorskiego Muzeum Sztuki Nowoczesnej (dalej: MoMA) Alfreda Barra, jaką była biała kostka, tzw. white cube $e^{11}$. Założeniem takiego modelu wystawienniczego było ograniczenie do minimum zbędnych bodźców, takich jak ostre kolory ścian czy tapety, oraz zagwarantowanie każdemu dziełu odpowiedniej ilości przestrzeni, w której ono samo stanowiłoby punkt centralny.

${ }^{11}$ K. Tzortzi, Museum Space: Where Architecture Meets Museology, Farnham 2015, s. 52-54. 


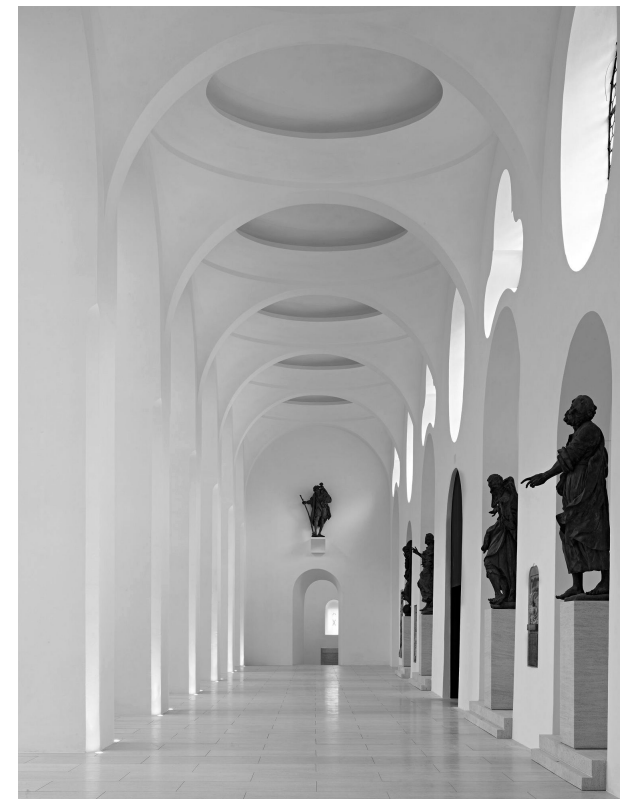

Il. 2. Kościół Moritzkirche w Augsburgu, wnętrze, projekt J. Pawson. Źródło: www.johnpawson.com/works/moritzkirche (dostęp: 12.04.2021).

Centralnym punktem kościoła pozostała niezmiennie apsyda o dziesięciu oknach, w której ustawiono jedną z zachowanych rzeźb G. Petersa - Chrystusa Zbawiciela oraz prosty, ciemny ołtarz. Naprzeciw uwagę przykuwają organy, o kolorze korespondującym z ciemnymi elementami wnętrza. Całość aranżacji jest bardzo jasna, nasycona dziennym światłem, pozbawiona jakichkolwiek zbędnych bodźców wizualnych.

W tym miejscu wartą uwagi kwestią jest pozbawienie przestrzeni zbędnych bodźców wizualnych, którą zastosowano po raz pierwszy we wspomnianym już modelu wystawienniczym nowojorskiego MoMA - the white cube. Wówczas priorytetem było wyizolowanie dzieła $\mathrm{z}$ dodanego kontekstu, jakim były historyczne przestrzenie ekspozycyjne. Badania pustej przestrzeni w kontekście oceny artystycznej wartości dzieł oraz możliwości ich zapamiętania dowiodły jednak niezbicie, że anonimowa przestrzeń, bez jakichkolwiek elementów dystynktywnych (często określana mianem „laboratorium”) ma negatywny wpływ na percepcję zwiedzających ${ }^{12}$. Można więc na tej podstawie zaryzykować stwierdzenie, że zredukowanie wnętrza do białych ścian, pozbawionych jakichkolwiek elementów charakterystycznych, może mieć negatywny wpływ na długofalową percepcję liturgii oraz obniżyć poziom satysfakcji z uczestnictwa w nabożeństwach. Jak słusznie zauważył Brian O’Doherty:

${ }^{12}$ D. Brieber, M. Nadal, H. Leder, In the white cube: Museum context enhances the valuation and memory of art, „Acta Psychologica”, 154 (2015) s. 36-42. 
biały kubik był środkiem przejściowym, który próbował wybielić przeszłość, a jednocześnie kontrolować przyszłość, odwołując się do rzekomo transcendentnych zasad istnienia i siły. Problem z zasadami transcendentnymi polega jednak na tym, że z definicji mówią one o innym świecie, nie o tym. To właśnie ten inny świat lub dostęp do niego, reprezentuje white cube ${ }^{13}$.

Być może to ambiwalentne odczucia towarzyszące odbiorowi białej, niemal pustej przestrzeni, stanowią powód, dla którego tak często projekty nowoczesnych re-aranżacji (wpisujące się w ogólnie panujące trendy) poddawane są surowej krytyce ze strony wiernych, o czym traktuje dalsza część tekstu.

W 2019 r. oddano do użytku odrestaurowane wnętrze niemieckiej Bazyliki St. Fidelis w Stuttgarcie. Kościół został wybudowany w latach 1924-1925 według projektu Clemensa Hummela, a za jego dekorację rzeźbiarską był odpowiedzialny Josef Zeitler ${ }^{14}$. Budowla ucierpiała w dużym stopniu podczas II wojny światowej, a jej odbudową w latach 60. XX wieku kierowali Rudolf i Maria Schwarz. Wówczas na nowo zorientowano bazylikę według postanowień Soboru Watykańskiego II. Kościół określany jest jako mariaż tendencji historyzujących oraz architektury z kręgu Nowej Rzeczowości.

Dominantą dekoracji były witrażowe okna oraz wolnostojące rzeźby w nawach bocznych. Ozdobnymi elementami architektonicznymi w prostym wnętrzu były wolutowe zdobienia pomiędzy łukami oddzielającymi nawy oraz drewniane kasetony na beczkowym sklepieniu nad nawą główną. W 2019 r. studio Schleicher Ragaller Architekten zakończyło prace nad rewitalizacją przestrzeni sakralnej w kościele St. Fidelis.

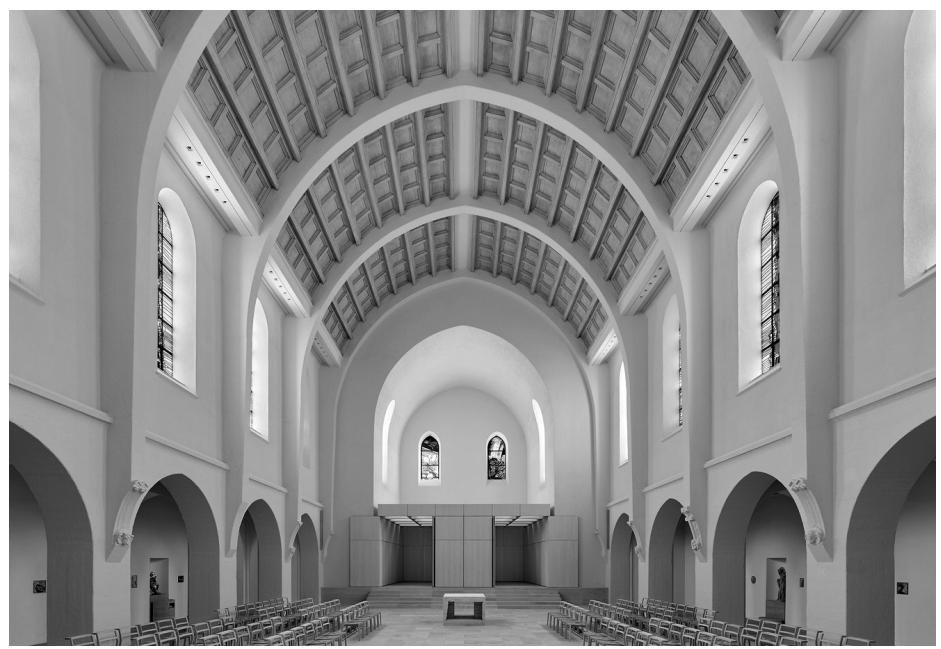

Il. 3. Kościół St. Fidelis w Sztuttgarcie, wnętrze, projekt Studio Schleicher Ragaller Architekten. Źródło: schleicher-ragaller.de/portfolio/kirche-st-fidelis-stuttgart (dostęp: 12.04.2021).

${ }^{13}$ B. O'Doherty, Inside the White Cube. The Ideology of the Gallery Space, San Francisco 1986, s. 11 .

${ }^{14}$ Zob. A. Kotzurek, R. Redies, Stuttgart von Tag zu Tag, 1900-1949. Eine Chronik, Tübingen 2009. 
Odsłonięte ściany zostały pomalowane na biały kolor, który optycznie powiększył przestrzeń. Podłogę wyłożono jasnym trawertynem, a ołtarz i ambonę o geometrycznej formie prostokąta wykonano z korespondującego z nim wizualnie wapienia. Oczyszczono również dębowe kasetony, dzięki czemu odzyskały one jasny, ciepły kolor, do którego nawiązują skromne krzesła zastępujące klasyczne ławy. W całości wyłożona drewnem została też przestrzeń za prezbiterium, będąca miejscem dyskretnego wkomponowania tabernakulum.

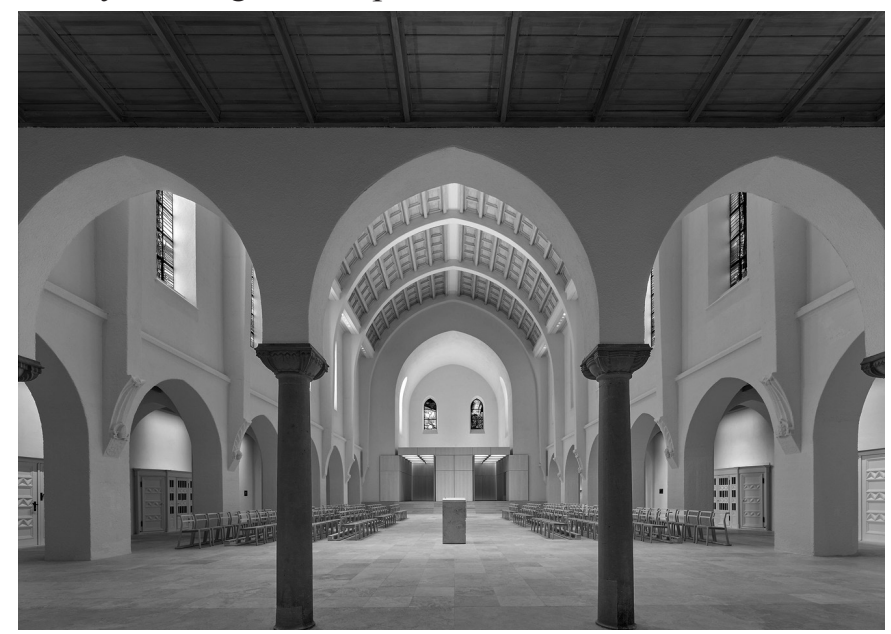

Il. 4. Kościół St. Fidelis w Sztuttgarcie, wnętrze, projekt Studio Schleicher Ragaller Architekten. Źródło: schleicher-ragaller.de/portfolio/kirche-st-fidelis-stuttgart (dostęp: 12.04.2021).

Architekci określili ją jako „przestrzeń ciszy”, która jest niejako „wewnętrznym prezbiterium kościoła"15. Dekoracyjne elementy, które pozostały z dawnego wystroju, to witraże, wolnostojące drewniane rzeźby oraz organy, stanowiące część wyposażenia świątyni od 2005 r. Dzięki wysiłkom podjętym przez studio Schleicher Ragaller Architekten kościół stał się jasny, a elementy o wartości historycznej zostały w pełni wyeksponowane. Zastosowanie naturalnych surowców wewszystkich częściach aranżacji pozwoliło nastworzenie atmosfery spokojuikontemplacji, bez charakterystycznego dla części minimalistycznych wnętrz „,chłodu", za który odpowiedzialna jest paleta barwna o zimnych podtonach. Największą zmianą we wnętrzu była reorganizacja miejsc dla wiernych. Choć pozostawiono układ dwurzędowy, to uczestnicy mszy siedzą obecnie naprzeciw siebie, a ołtarz ustawiono pomiędzy nimi, na tej samej wysokości. Jest to nawiązanie do postulatów Konstytucji o Liturgii Świętej, która mówi, iż „przy budowie świątyń należy troskliwie dbać o to, aby były przystosowane do sprawowania liturgii oraz ułatwiały wiernym czynny w niej udział"16. Dzięki skróceniu dystansu między

${ }^{15}$ P. Pintos, Church St. Fidelis in Stuttgart / Schleicher Ragaller Architekten, www.archdaily. com/948293/church-st-fidelis-in-stuttgart-schleicher-ragaller-architekten (dostęp: 12.04.2021).

${ }^{16}$ Sobór Watykański II, Konstytucja o liturgii świętej „Sacrosanctum concilium”, Rzym 1963, nr 124. 
wiernymi oraz bliskości celebransa charakter liturgii ulega zmianie i staje się bardziej kameralny. Założeniem wspólnoty było też stworzenie miejsca, które sprzyjałoby kontemplacji i duchowości, będącymi przeciwieństwem pędu życia, o czym wspominają związani z przybytkiem duchowni ${ }^{17}$.

Nieco inny model minimalistycznej aranżacji wnętrza otrzymał francuski kościół Église Saint-Hilaire w miejscowości Melle. Jego historia sięga początków XII wieku, gdy kamienny budynek zastąpił drewnianą świątynię z IX wieku ${ }^{18}$. Jako że świątynia usytuowana była na szlaku wiodącym do Santiago de Compostela, otrzymała typowy dla kościołów pielgrzymkowych układ, z trzema apsydiolami wokół apsydy centralnej. Do nawy głównej prowadzą schody, co potęguje efekt wizualnej wertykularyzacji sklepienia. Całość wnętrza jest surowa, utrzymana w tonacji jasnego kamienia, dzięki czemu w świątyni jest jasno pomimo niewielkich, wysoko usytuowanych okien. Jedynymi ozdobami są kapitele kolumn oraz portal wejściowy. W $2011 \mathrm{r}$. architekt Mathieu Lehanneur ${ }^{19}$, specjalizujący się w niespotykanych rozwiązaniach we wnętrzach komercyjnych, sfinalizował projekt rewitalizacji przestrzeni liturgicznej. Zmianie uległa strefa chóru z ołtarzem oraz znajdującą się za nim częścią pełniąca funkcję baptysterium. Ołtarz oraz ambonę o bardzo prostych, geometrycznych formach wykonano $\mathrm{z}$ alabastru o kolorze przypominającym kamień, z którego zbudowano świątynię. Obie struktury ustawiono na podium o organicznym kształcie, otoczonym dookoła schodami. Wykonano je z białego marmuru, który potęguje wrażenie świetlistości w obrębie ołtarza.

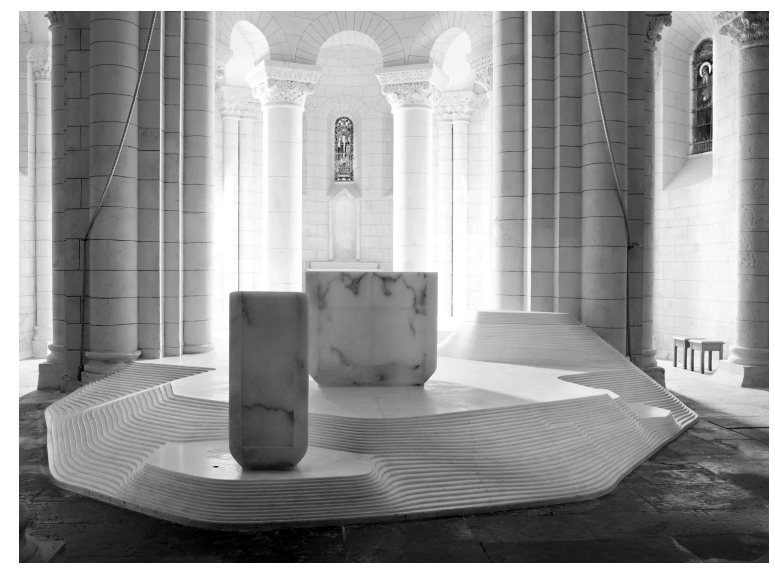

Il. 5. Kościół Église Saint-Hilaire, Melle, wnętrze, projekt Mathieu Lehanneur.

Źródło: www.mathieulehanneur.fr/project/saint-hilaire-church-164 (dostęp: 12.04.2021).

${ }^{17}$ Por. Kirchenraums in St. Fidelis, www.station-s.de/kirche/neuekirche/kirchenraum (dostęp: 12.04.2021).

${ }^{18}$ N. Gaillard, Pays d'Art et d'Histoire du Pays Mellois laissez-vous conter le chœur de Saint Hilaire de Melle, Melle 2012, b.n.

${ }^{19}$ Por. Mathieu Lehanneur, red. R. Klanten, M. Le Fort, Berlin 2012. 
Całość struktury, choć bardzo nowoczesna zarówno pod względem kształtu, jak i braku ornamentyki, doskonale koresponduje z zastanym historycznym wnętrzem obiektu. Dzięki symbiotycznej relacji kolorystycznej udało się stworzyć strefę sacrum, która nie odwraca uwagi od istoty liturgii, a wręcz powoduje skupienie na niej uwagi. Przykład kościoła w Melle dobitnie ukazuje tendencje do adaptowania rozwiązań, których forma jest sama w sobie dekoracją, a możliwa jest do uzyskania dzięki nowoczesnym metodom projektowym. Coraz częściej bowiem twórcy architektury sakralnej, jak zauważa P.P. Trębacz, ,starają się wykorzystać - o ile warunki ekonomiczne inwestora na to pozwalają - najnowsze osiągnięcia techniczne i technologiczne, myśl konstrukcyjną inżynierów i informatyków, by projektować oryginalne konstrukcje"20.

Na gruncie polskim pojawiają się również propozycje radykalnego unowocześnienia przestrzeni, czego przykładem jest projekt Hanczar Studio. Architekci Szymon Hanczar i Przemysław Słowik stworzyli model rewitalizacji wnętrz kościoła w Żórawinie pod Wrocławiem. Kościół pod wezwaniem św. Józefa Oblubieńca ${ }^{21}$ został zbudowany w 1913 r. jako ewangelicki, ale już po II wojnie światowej uległ został przebudowany i przekształcony na świątynię Kościoła rzymskokatolickiego. W latach 70. i 80. XX wieku wykonano niewielkie prace, jednak nie podjęto próby całkowitej restauracji wnętrz z pierwszej połowy XX wieku. Poza kilkoma zabytkami przeniesionymi z żórawińskiego kościoła Świętej Trójcy wnętrze nie posiada licznych elementów zabytkowych zachowanych in situ. Wyjątek stanowią polichromie pokryte kilkoma warstwami farby, których stan stanowi wciąż kwestię otwartą, jak również witrażowe okna z lat 50. ubiegłego wieku. Propozycja Hanczar Studio zakłada całkowitą metamorfozę przestrzeni przy użyciu prostych środków.

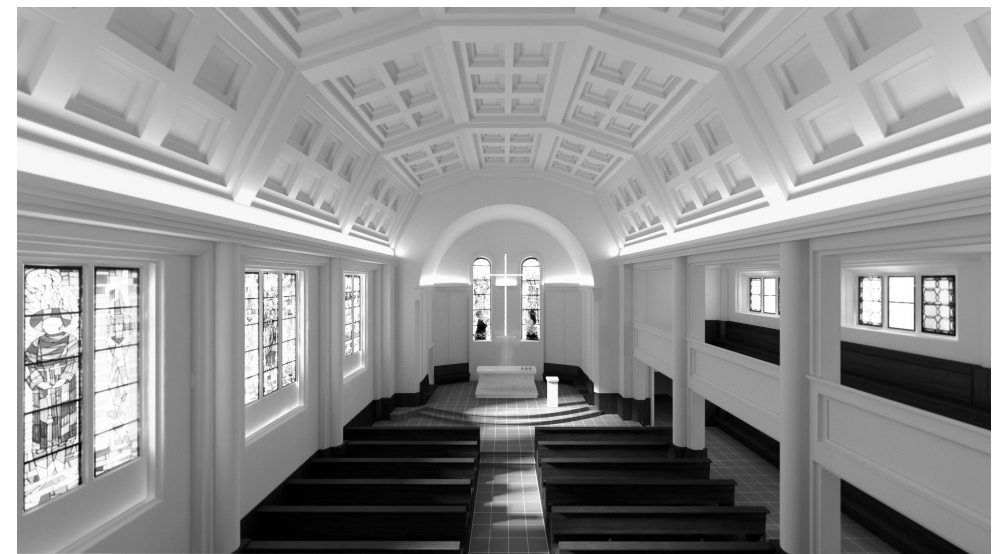

Il. 6. Kościół św. Józefa Oblubieńca, wizualizacja wnętrza, projekt Sz. Hanczar i P. Słowik. Źródło www.facebook.com/hanczarstudio (dostęp: 12.04.2021).

${ }^{20}$ P.P. Trębacz, Piękno i technika we współczesnej architekturze sakralnej, „Architecturae et Artibus", 8 (2016) nr 3, s. 173-180, s. 179.

${ }^{21}$ W. Rozynkowski, Święty Józef jako patron parafii i kościołów parafialnych w Polsce, „Kaliskie Studia Teologiczne", 2 (2003) s. 81-95. 
Żółte ściany i kasetonowy sufit według projektu pomalowane miały być na biały kolor, podłoga utrzymana w odcieniu jasnej szarości, a jedynymi elementami barwnymi pozostałyby witraże oraz ławy i listwy przypodłogowe wykonane z ciemnego drewna. Rewitalizacja zakłada również ustawienie prostego, białego ołtarza, który nie odwracałby wizualnie uwagi od dwóch flankujących go witraży. Dzięki tym prostym zabiegom wnętrze byłoby bardzo jasne, a światło przenikające przez witraże stałoby się centralnym punktem dekoracyjnym ${ }^{22}$. Coraz częściej obiekty o krótkiej historii oraz znacznym stopniu utracenia pierwotnej dekoracji zostają poddane unowocześnieniu wnętrza $\mathrm{w}$ duchu minimalizmu, co przywodzi na myśl kwestie związane z kontemplacją niezakłóconą nadmiarem bodźców i pełnym odbiorem liturgii.

Skrajny minimalizm nie jest jednak na gruncie rodzimym trendem, który byłby akceptowany przez ogół wiernych. Przykładem świadczącym niezbicie o przywiązaniu do tradycji jest kwestia katowickiego kościoła dominikanów (parafia Przemienienia Pańskiego), gdzie projekt transformacji wnętrz nie spotkał się z aprobatą wiernych ${ }^{23}$. Modernistyczny kościół z lat 1974-1977, którego architektem był Tadeusz Eugeniusz Łobos ${ }^{24}$, posiada proste wnętrze o znikomym poziomie dekoracji. Jego betonowe ściany korespondują wizualnie z prostą, geometryczną fasadą. Ciekawymi, z estetycznego punktu widzenia, elementami wnętrza są okna po obu stronach nawy, o asymetrycznym układzie i witrażowej dekoracji po prawej stronie. Nowa koncepcja przebudowy wnętrza została zaprezentowana przez o. Tomasza Golonkę w 2020 r., a jej autorami są: Tomasz Chmiel (Nowe Biuro), Grzegorz Hańderek (Artysta Wizualny, ASP w Katowicach), Joanna i Wojciech Małeccy (Małeccy Biuro Projektowe), Bartłomiej Nawrocki (Jojko+Nawrocki Architekci), o. Tomasz Golonka (przeor klasztoru dominikanów w Katowicach) oraz o. Paweł Lasek (syndyk klasztoru dominikanów w Katowicach) ${ }^{25}$. Wraz z decyzją o remoncie wnętrza kościoła wiadome było, że zostaną wprowadzone znaczne zmiany i nadane cechy charakterystyczne dla architektury minimalistycznej. Świadczyły o tym oficjalne wypowiedzi ze strony klasztoru dominikanów, które publikowane były w prasie lokalnej. Jak poinformowano wspólnotę już w 2019 r.:

w trakcie remontu ze ścian mają być zdjęte płyty kartonowo-gipsowe. Zmienić ma się też wygląd stropu - zniknie obecna charakterystyczna fala. Inaczej będzie wyglądać również ołtarz (...) plan przewiduje też wymianę posadzki oraz

${ }^{22}$ Więcej na temat projektu oraz założeń architektury wnętrz zob. K. Białas, Projekt przebudowy kościoła w Katowicach, www.whitemad.pl/bez-zbednych-dodatkow-tak-architekci-chca-zrewitalizowac-przedwojenny-kosciol (dostęp: 12.04.2021).

${ }^{23}$ K. Pachelska, Katowice: awantura o wystrój kościoła. Ascetyczne do bólu wnętrze kościoła dominikanów przy Sokolskiej nie podoba się wiernym, „Dziennik Zachodni”, 16.02.2020, dziennikzachodni.pl/katowice-awantura-o-wystroj-kosciola-ascetyczne-do-bolu-wnetrze-kosciola-dominikanow-przy-sokolskiej-nie-podoba-sie-wiernym/ar/c9-14715608 (dostęp: 12.04.2021).

${ }^{24}$ A. Borowik, Stownik architektów, inżynierów i budowniczych zwiazanych z Katowicami w okresie międzywojennym, Katowice 2012, s. 86-90.

${ }^{25}$ Zob. Dominikanie Katowice, katowice.dominikanie.pl/2020/01/18/remont-kosciola-3 (dostęp: 12.04.2021). 
renowację ławek (...) z wizualizacji wynika, że świątynia po zakończeniu prac będzie jaśniejsza ${ }^{26}$.

Finalna wizualizacja zaprezentowana na spotkaniu $\mathrm{z}$ wiernymi przyniosła znaczne zmiany w planowanym wyglądzie kościoła.

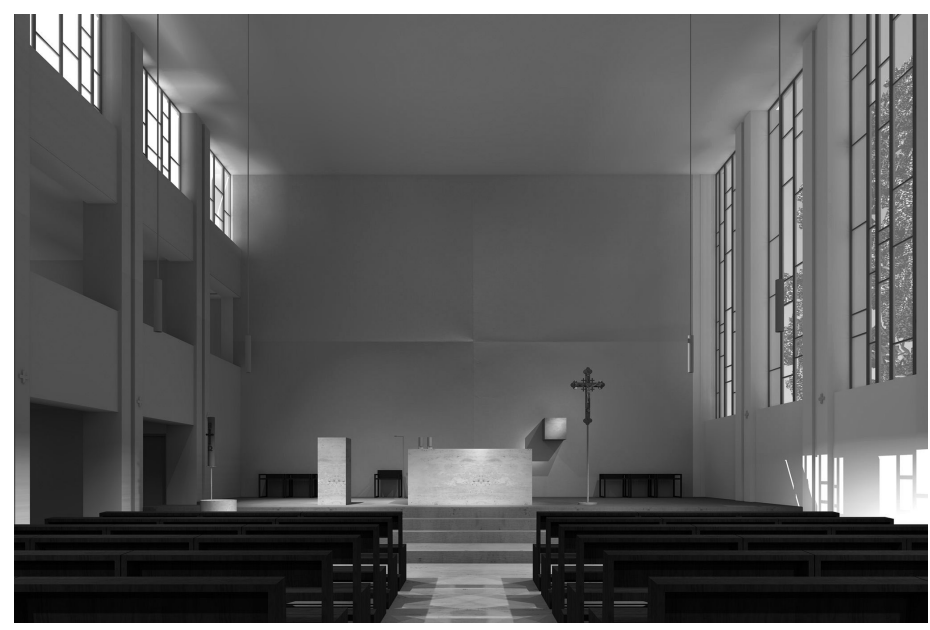

Il. 7. Kościół dominikanów (Parafia Przemienienia Pańskiego) w Katowicach, wizualizacja wnętrza, projekt T. Chmiel i in.

Źródło: Dominikanie Katowice (dostęp: 12.04.2021).

Wszystkie ściany miały być białe i pozbawione zdobień. Ściana za ołtarzem podzielona na cztery kwadraty o wygiętych brzegach zarysowywać miała wymownie kształt krzyża. Ołtarz i ambona, podobnie jak podłoga, wykonane miały zostać z bardzo jasnego kamienia, by wizualnie harmonizować z resztą założenia. Również wykorzystanie szlachetnego materiału, jakim jest kamień, spełnia wymogi stawiane przez prawo liturgiczne ${ }^{27}$. Jedynym kontrastowym elementem pozostać miały ciemne, proste ławy oraz podziały okienne. Wnętrze oświetlać miało światło dzienne, a wieczorami wiszące lampy sufitowe w obrębie nawy głównej i ołtarza. Zachowana miała być zasada oświetlenia ołtarza jako centralnej części liturgii ${ }^{28}$. Warto dodać, iż skrajna redukcja „klasycznych” środków wyrazu podyktowana była wizją kościoła, która odnosiła się zarówno do reguły klasztoru oraz współczesnego tempa życia wiernych, które oparte winny być na prostocie. Dlatego też, jak tłumaczyli zakonnicy uczestniczący w tworzeniu projektu:

${ }^{26}$ M. Bednarek, Kościót przy Sokolskiej w Katowicach szykuje się do dużego remontu, „Gazeta Wyborcza”, 24.04.2019, katowice.wyborcza.pl/katowice/7,35063,24693460,kosciol-przy-sokolskiej-w-katowicach-szykuje-sie-do-duzego-remontu.html (dostęp: 12.04.2021).

${ }^{27}$ A. Matyszewski, Ottarz wczoraj i dziś, „Msza Święta”, (2008) z. 7-8, s. 23-25.

${ }^{28}$ J. Nowak, J. Rusiecki, W. Mieszkowski, K. Kucza-Kuczyński, J. Mieczkowski, Biuletyn Liturgiczny, „Collectanea Theologica”, 78 (2008) nr 1, s. 81-129, s. 108. 
w warstwie formalnej mamy do czynienia z geometrią determinowaną materią i światłem, jego modulacją i zmiennością. Światło odpowiada za kreowanie atmosfery tego miejsca - atmosfery sprzyjającej wyciszeniu i kontemplacji zbudowanej na kontraście między materialną trwałością struktury, a ulotnym charakterem oddziaływania czynników naturalnych ${ }^{29}$.

Po ogłoszeniu nowego planu pojawiły się liczne głosy sprzeciwu wobec proponowanej aranżacji. Większość odnosiła się do osobistych odczuć: ,projekt to dążenie do skrajnego minimalizmu. Jak bym wszedł do takiego kościoła, to poczułbym chłód i pustkę, i ciężko byłoby mi skupić się na spotkaniu z Bogiem" bądź ,reszta przygnębiająca jak świat bez Boga"30.

Bardzo nacechowaną emocjonalnie polemikę z projektem toczyła E. Chudyba, która w swoim tekście pt. Pan Jezus nie urodził się w labolatorium negowała wszelkie próby wprowadzania innowacji do przestrzeni sakralnej, pisząc, iż ,nowoczesność istotowo jest antychrześcijańska"31. Świadczy to nie tylko o polaryzacji gustów wśród wiernych oraz odwiedzających świątynię, ale również o głęboko zakorzenionej niechęci do jakichkolwiek zmian, które choć wpisują się w założenia Vaticanum II, nie licują najwidoczniej z przyzwyczajeniami wiernych. Ponadto należy wspomnieć, iż minimalizm, który zachowuje strukturę niezbędną do sprawowania liturgii, nie stoi w sprzeczności z normami postępowania dotyczącymi sztuki kościelnej ${ }^{32}$.

Przywołane przykłady świadczą o stopniowym adaptowaniu tendencji minimalistycznych, obecnych od dawna w wystroju wnętrz prywatnych, komercyjnych i użyteczności publicznej, do aranżacji miejsc kultu. Nie dziwi fakt, że tak wiele nowopowstałych świątyń wybiera model nowoczesny, współgrający z bryłą architektoniczną, gdyż rozwiązanie takie zapewnia spójność i kultywuje przyjęte zasady decorum. Polaryzacja opinii publicznej dotyczy jednak najczęściej kwestii rewitalizacji dawnych wnętrz wedle panujących obecnie tendencji. Brak utrzymania zasady konsekwencji stylowej powoduje w wielu środowiskach nieuzasadniony sprzeciw, który nie jest poparty przesłankami natury konserwatorskiej ani liturgicznej ${ }^{33}$. Patrząc przez pryzmat pryncypiów ochrony dóbr kultury, zawartych w dokumentach doktrynalnych, poczynając od Karty Ateńskiej, a kończąc na Dokumencie z Valetty ${ }^{34}$, nie wybrzmiewa konieczność przeprowadzania rewitalizacji obiektu w duchu rewiwalistycznym, jeśli nie zachował się wystarczający ma-

${ }^{29}$ Dominikanie Katowice, katowice.dominikanie.pl/2020/01/18/remont-kosciola-3/ (dostęp: 12.04.2021).

${ }^{30}$ Pachelska, Katowice: awantura o wystrój kościoła (dostęp: 12.04.2021).

${ }^{31}$ E. Chudyba, Pan Jezus nie urodzit się w labolatorium, wersjerobocze.blogspot.com/2020/01/ pan-jezus-nie-urodzi-sie-w-labolatorium.html (dostęp: 12.04.2021).

${ }^{32}$ Normy postępowania w sprawach sztuki kościelnej, uchwalone przez Konferencję Episkopatu Polski dn. 25.01.1973 roku, oprac. Krakowiak, L. Adamowski, Lublin 1994, s. 311-330.

${ }^{33}$ Nie ma przesłanek, które opowiadałyby się jednoznacznie przeciwko modelowi, który wykorzystano w przywołanych przykładach, por. M. Leszczyński, Ochrona zabytków sztuki sakralnej w świetle aktualnego prawa Kościoła katolickiego, „Muzealnictwo”, 49 (2008) s. 79-88.

${ }^{34}$ Zob. Vademecum Konserwatora Zabytków Międzynarodowe Normy Ochrony Dziedzictwa Kultury (edycja 2015), oprac. B. Szmygin, Warszawa 2015, s. 27-204. 
teriał historyczny in situ. Jednak nie wydaje się to wystarczającą przesłanką do zaniechania tego typu rozwiązań. Jak rzeczowo skonkludował H. Nadrowski, w duchu błędnie przyświecającego tradycjonalizmu

budowano kościoły na zasadzie ciągle powtarzanych - niestety, niby wyuczonych wersów - periodów i konwencji stylistycznych epok minionych. Często powstawały nie tyle repliki obiektów klasycystycznych, barokowych czy gotyckich, ile realizacje nieudolne i pozbawione jakiejkolwiek twórczej inwencji ${ }^{35}$.

Badania socjologiczne z lat 1991-2012 dowodzą, iż „praktyki religijne ukazują w najbardziej wyrazisty sposób społeczny wymiar wiary religijnej splatającej się z kulturowymi tradycjami, czy inaczej mówiąc, ubranej w kostium kulturowy"36.

Najprawdopodobniej uwidacznia się to również w percepcji wnętrz sakralnych, których minimalistyczny obraz nie koresponduje z utrwaloną przez stulecia potrydencką wizją kościoła. Swiadczy o tym przywołany przykład rewitalizacji w Katowicach, która stała się bezpośrednią przyczyną konfliktu w środowisku parafian. Skrajna niechęć do minimalizmu lub nawet redukcjonizmu wydaje się nieintuicyjna nawet wobec prac z zakresu psychologii, które dowodzą, że proste wnętrza sprzyjają skupieniu i kontemplacji - aspektom prymarnym w obliczu funkcji miejsca kultu ${ }^{37}$.

Istotnym elementem wnętrz minimalistycznych, które zyskują na popularności również w kontekście rewitalizacji, jest metaforyczne i fizyczne zbliżenie wiernych do celebransa. Jak pokazały przykłady, coraz bardziej zatracany jest dystans i hierarchizacja, ustępując miejsca poczuciu wspólnoty. Jak słusznie zauważa A. Szybowska:

Vaticanum II zbliżył liturgię do wiernych, ujął ją w sposób dynamiczny - jako proces podlegający przekształceniom w zależności od rozmaitych uwarunkowań, na przykład rodzaju wspólnoty biorącej udział w obrzędach (msze z udziałem dzieci czy rolników). Pojawił się nowy termin: „,inkulturacja” - dostosowywanie liturgii do kultury i zwyczajów poszczególnych krajów i narodów. Przebudowano architekturę prezbiterium, dzięki czemu przestrzeń oddzielająca wiernych i celebransa istotnie się zmniejszyła. Celebransi otrzymali znaczną swobodę w kształtowaniu obrzędów oraz możliwość sprawowania eucharystii przodem do ludu ${ }^{38}$.

${ }^{35}$ H. Nadrowski, Budowa kościoła. Aspekt teologiczny i pastoralny, „Poznańskie Studia Teologiczne", 17 (2004) s. 265-303, s. 269.

${ }^{36} \mathrm{~J}$. Mariański, Praktyki religijne w Polsce w procesie przemian, w: Postawy społeczno-religijne Polaków 1991-2012, red. L. Adamczuk, E. Firlit, W. Zdaniewicz SAC, Warszawa 2013, s. 59102, s. 60 .

${ }^{37}$ Zob. m.in. S. Augustin, N. Frankel, C. Coleman, Place Advantage: Applied Psychology for Interior Architecture, Hoboken 2009, s. 1-15, 69-80; P. Rodemann, Patterns in Interior Environments: Perception, Psychology, and Practice, New York 1999, s. 80-105.

${ }^{38}$ A. Szybowska, ,Homo liturgicus”: ,, antropologiczny zwrot” w opisach eklezjalnych po Soborze Watykańskim II, w: Antropologia kultury - antropologia literatury, red. E. Kosowska, E. Jaworski, Katowice 2005, s. 136-145. 
Jest to ważna zmiana, bardzo mocno wyartykułowana, szczególnie w minimalistycznych budowlach, które już na poziomie architektury budynku zatracają monumentalne proporcje na rzecz wnętrz sprzyjających wyciszeniu, które nie są obarczone brzemieniem skrajnego monumentalizmu.

Odwołując się do wątku dystansu między wiernymi i celebransem, należy podjąć kwestie związane z podświadomym odbiorem komunikatu, który jest obiektem interdyscyplinarnych badań z obszaru nauk społecznych, głównie psychologii ${ }^{39}$. Warto pobieżnie przybliżyć najważniejsze dokonania na tym polu, które ukazałyby $\mathrm{w}$ zarysie rolę przestrzeni w percepcji treści dogmatycznych oraz w emotywnym zaangażowaniu wiernych. Już w latach 60 . udowodniono, że skrócenie fizycznego dystansu między rozmówcami (a tym samym można założyć, że również między przekazem odprawiającego mszę a jej uczestnikami) potęguje skupienie na samej treści. Natomiast zbyt mała odległość skutkuje przeniesieniem atencji odbiorcy na fizyczne cechy rozmówcy, zakłócając odbiór komunikatu werbalnego ${ }^{40}$. Rozumienie owego mechanizmu mogło stać u podstaw zniwelowania odległości między ołtarzem a ławami, która w dalszym ciągu jest jednak zauważalna. Kolejnym aspektem, który wiąże się z redukcjonizmem, jest optyczne powiększenie przestrzeni. Studia z 2012 r. wiążące atmosferę zaangażowania rozmówców i poziomu intymności z dostępną przestrzenią pokazały, że nawet wizualnie większa przestrzeń sprzyja wzrostowi intymności w komunikacji ${ }^{41}$. Zakładając emocjonalny charakter uczestnictwa w obrzędach, większa powierzchnia świątyni pozwala na zachowanie wrażenia względnego odosobnienia przy zachowaniu pożądanej bliskości celebransa. Również kolorystyka i niezakłócony dostęp do światła dziennego mają znaczący wpływ na nastrój oraz zdolności poznawcze ${ }^{42}$. Zakładając, że jasne puste wnętrza sprawiają wrażenie lepiej oświetlonych i symulują światło dzienne, teoretycznie powinny być postrzegane jako pomocne w osiągnięciu odpowiedniego nastroju.

Konkludując, minimalistyczne rewitalizacje wnętrz kościołów niezbicie dowodzą, że istnieje bardzo silna potrzeba minimalizacji bodźców wizualnych, która wynika bezpośrednio ze współczesnego stylu życia. Szczególnie świątynie powinny jawić się jako miejsca wyciszenia i kontemplacji, pozbawione przepychu i nadmiaru. Niewątpliwie należy również wziąć pod uwagę globalny zwrot ku redukcjonizmowi w architekturze zarówno przestrzeni publicznych, jak i prywatnych, który znajduje bezpośrednie przełożenie na nową estetykę wystroju świątyń. Percepcja nowoczesnego kościoła wydaje się również łatwiejsza dla wiernych, jako że „budowla sakralna powinna być dziełem doby współczesnej, dziełem wy-

${ }^{39}$ Por. H-T. Hamdy Mahmoud, Interior Architectural Elements That Affect Human Psychology and Behavior, „ARChive”, 1 (2017) nr 1, https://ssrn.com/abstract=3055621 (dostęp: 27.08.2021).

${ }^{40}$ Por. badania na temat fizycznego dystansu i perswazji: S. Albert, J. M. Dabbs, Physical distance and persuasion, ,Journal of Personality and Social Psychology”, (1970) nr 15, s. 265-270.

${ }^{41}$ V. Okken, Th. van Rompay, A. Pruyn, Room to Move: On Spatial Constraints and Self-Disclosure During Intimate Conversations, „Environment and Behavior”, 45 (2012) nr 6, s. 737-760.

${ }^{42}$ R. Küller, S. Ballal, Th. Laike, B. Mikellides, G. Tonello, The impact of light and colour on psychological mood: A cross-cultural study of indoor work environments, „Ergonomics”, 49 (2006) nr 14, s. 1496-1507. 
powiedzianym zrozumiałym językiem współczesnego człowieka, a nie bezduszną kopią stylów epok minionych czasów"43.

Analizując przykłady minimalistycznych rewitalizacji, daje się wysnuć wniosek, iż redukcjonizm staje się coraz popularniejszą praktyką, daleką jednak od bycia tendencją dominującą. Pewne kwestie, mogące wyjaśnić taki stan rzeczy, poddają się fragmentarycznemu wyjaśnieniu dzięki badaniom psychologów na temat pecepcji przestrzeni. Są one jednak dalekie od pełnej miarodajności z uwagi na swoje zogniskowanie na środowiskach komercyjnych. Wciąż brak jest wyczerpujących badań, które pozwoliłyby zrozumieć, w jaki sposób (jeśli w ogóle) poszczególne zmienne w wystroju wnętrz sakralnych (kolorystyka, metraż i kubatura pomieszczeń, odległości pomiędzy poszczególnymi strefami, oświetlenie oraz liczba dekoracji i ich rodzaj) mogą wpływać na poziom skupienia uczestników nabożeństw, ich rozumienie przekazywanej treści lub intensywność zaangażowania emocjonalnego. Stąd też wartym uwzględnienia postulatem jest przeprowadzenie badań interdyscyplinarnych w obszarze psychologii, socjologii oraz architektury wnętrz, które pozwoliłyby na lepsze poznanie przyczyny tak spolaryzowanych preferencji wiernych wobec modelu architektonicznego, który w zamierzeniu dążył do zniwelowania zbędnego szumu między wiernymi, a przekazem liturgicznym.

\section{REFERENCES / BIBLIOGRAFIA}

\section{Źródła}

Dokumenty Soborów Powszechnych. Tekst łaciński i polski, t. 4/1: (1511-1870) Lateran V, Trydent, Watykan I, oprac. A. Baron, H. Pietras SJ, Kraków 2004.

Sobór Watykański II, Konstytucja o liturgii świętej „Sacrosanctum concilium”, Rzym 1963.

Normy postępowania w sprawach sztuki kościelnej, uchwalone przez Konferencję Episkopatu Polski dn. 25.01.1973 r., oprac. Cz. Krakowiak, L. Adamowski, Lublin 1994.

Reformationes Generales ad clerum et populum Dioecesis Cracoviensis pertinentes ab Illustrissimo et Reverendissimo Domino D. Martino Szyszkowski (...) episcopo Cracoviensi (...) in Synodo Dioecesano sanictae et promulgatae A. D. MDCXXI, Kraków 1621, s. 152-155.

\section{Opracowania}

Albert Stuart, Dabbs James Jr, Physical distance and persuasion, „Journal of Personality and Social Psychology", (1970) nr 15, s. 265-270.

Augustin Sally, Frankel Neil, Coleman Cindy, Place Advantag. Applied Psychology for Interior Architecture, Hoboken 2009.

Bertoni Franco, Minimalist Architecture, Basel 2002.

Brieber David, Nadal Marcos, Leder Helmut, In the white cube. Museum context enhances the valuation and memory of art, ,Acta Psychologica”, 154 (2015) s. 36-42.

${ }^{43}$ J. Nowak, J. Rusiecki, W. Mieszkowski, K. Kucza-Kuczyński, J. Mieczkowski, Biuletyn Liturgiczny, s. 91. 
Borowik Aneta, Słownik architektów, inżynierów i budowniczych związanych z Katowicami w okresie międzywojennym, Katowice 2012.

Eser Thomas, Georg Peters Bildhauerarbeiten für die Moritzkirche, w: Das ehemalige Kollegiatstift St. Moritz in Augsburg (1019-1803): Geschichte, Kultur, Kunst, Lindenberg 2006, s. 369-398.

Gaillard Nathalie, Pays d'Art et d'Histoire du Pays Mellois laissez-vous conter le chour de Saint Hilaire de Melle, Melle 2012.

Gropius Walter, Petnia architektury, Kraków 2014.

Hamdy Mahmoud Heba-Talla, Interior Architectural Elements That Affect Human Psychology and Behavior, „ARChive”, 1 (2017) nr 1, https://ssrn.com/abstract=3055621 (dostęp: 27.08.2021).

Kollegiatstift St. Moritz in Augsburg (1019-1803): Geschichte, Kultur, Kunst, red. G.M. Müller, Lindenberg 2006, s. 369-398.

Kotzurek Annegret, Redies Rainer, Stuttgart von Tag zu Tag, 1900-1949. Eine Chronik, Tübingen 2009.

Królikowski Janusz, Sobór Trydencki i jego inspirujace znaczenie, w: Dzieje diecezji tarnowskiej, t. 7: Synody Diecezji Tarnowskiej, tred. A. Żurek, J. Soprych, Kraków 2017, s. 47-56.

Küller Rikard, Ballal Seifeddin, Laike Thorbjorn, Mikellides Byron, Tonello Graciela, The impact of light and colour on psychological mood: A cross-cultural study of indoor work environments, „Ergonomics”, 49 (2006) nr 14, s. 1496-1507.

Leszczyński Mariusz, Ochrona zabytków sztuki sakralnej w świetle aktualnego prawa Kościoła katolickiego, „Muzealnictwo”, 49 (2008) s. 79-88.

Mariański Janusz, Praktyki religijne w Polsce w procesie przemian, w: Postawy społeczno-religijne Polaków 1991-2012, red. L. Adamczuk, E. Firlit, W. Zdaniewicz SAC, Warszawa 2013, s. 59-102.

Mathieu Lehanneur, red. R. Klanten, M. Le Fort, Berlin 2012.

Matyszewski Adam, Ottarz wczoraj i dziś, „Msza Święta”, (2008) z. 7-8, s. 23-25.

Morris Alice, John Pawson: Anatomy of Minimum, London 2019.

Nadrowski Henryk, Budowa kościoła. Aspekt teologiczny i pastoralny, „Poznańskie Studia Teologiczne", 17 (2004) s. 265-303.

Nowak Jacek, Rusiecki Jan, Mieszkowski Witold, Kucza-Kuczyński Konrad, Mieczkowski Janusz, Biuletyn Liturgiczny, „Collectanea Theologica”, 78 (2008) nr 1, s. 81-129.

Obendorf Hartmut, Minimalism: Designing Simplicity, London 2009.

O'Doherty Brian, Inside the White Cube. The Ideology of the Gallery Space, San Francisco 1986.

Okken Vanessa, van Rompay Thomas, Pruyn Ad, Room to Move. On Spatial Constraints and Self-Disclosure During Intimate Conversations, „Environment and Behavior”, 45 (2012) nr 6, s. 737-760.

Rodemann Patricia, Patterns in Interior Environments: Perception, Psychology, and Practice, New York 1999.

Rozynkowski Waldemar, Święty Józef jako patron parafii $i$ kościołów parafialnych w Polsce, „Kaliskie Studia Teologiczne”, 2 (2003) s. 81-95.

Szybowska Antonina, „Homo liturgicus”: ,antropologiczny zwrot” w opisach eklezjalnych po Soborze Watykańskim II, w: Antropologia kultury - antropologia literatury, red. E. Kosowska, E. Jaworski, Katowice 2005, s. 136-145.

Trębacz Piotr P., Piękno i technika we współczesnej architekturze sakralnej, „Architecturae et Artibus", 8 (2016) nr 3, s. 173-180.

Tzortzi Kali, Museum Space: Where Architecture Meets Museology, Farnham 2015. 
Vademecum Konserwatora Zabytków Międzynarodowe Normy Ochrony Dziedzictwa Kultury (edycja 2015), oprac. B. Szmygin Warszawa 2015, s. 27-204.

\section{Netografia}

Bednarek Michalina, Kościół przy Sokolskiej w Katowicach szykuje się do dużego remontu, „Gazeta Wyborcza”, 24.04.2019, katowice.wyborcza.pl/katowice/7,35063,246934 60,kosciol-przy-sokolskiej-w-katowicach-szykuje-sie-do-duzego-remontu.html (dostęp: 12.04.2021).

Białas Kamil, Projektprzebudowy kościoła wKatowicach, www.whitemad.pl/bez-zbednych-dodatkow-tak-architekci-chca-zrewitalizowac-przedwojenny-kosciol (dostęp: 12.04.2021).

Chudyba Ewa, Pan Jezus nie urodzit się w labolatorium, wersjerobocze.blogspot. com/2020/01/pan-jezus-nie-urodzi-sie-w-labolatorium.html (dostęp: 12.04.2021).

Dokument z Nara o autentyzmie, 1994, tłum. M. Fokt-Willmann, zabytki.olsztyn.eu/fileadmin/zabytki/pdf/dokument_z_Nara_o_autentyzmie_1994_r..pdf(dostęp: 12.04.2021).

Dominikanie Katowice, katowice.dominikanie.pl/2020/01/18/remont-kosciola-3 (dostęp: 12.04.2021).

Kirchenraums in St. Fidelis, www.station-s.de/kirche/neuekirche/kirchenraum (dostęp: 12.04.2021).

Pachelska Katarzyna, Katowice: awantura o wystrój kościoła. Ascetyczne do bólu wnętrze kościoła dominikanów przy Sokolskiej nie podoba się wiernym, „Dziennik Zachodni”, 16.02.2020, dziennikzachodni.pl/katowice-awantura-o-wystroj-kosciola-ascetycznedo-bolu-wnetrze-kosciola-dominikanow-przy-sokolskiej-nie-podoba-sie-wiernym/ ar/c9-14715608 (dostęp: 12.04.2021).

Pintos Paula, Church St. Fidelis in Stuttgart / Schleicher Ragaller Architekten, www.archdaily.com/948293/church-st-fidelis-in-stuttgart-schleicher-ragaller-architekten (dostęp: 12.04.2021). 


\title{
SELECTED ASPECTS OF MINIMALIST REARRANGEMENTS OF CHURCH INTERIORS AFTER 2000
}

\begin{abstract}
This text explores the subject of minimalist renovations in the sacred interiors of the Roman Catholic Church, based on a selection of representative examples, geographically and culturally diversified. Starting from the assumptions of the Second Vatican Council and the artistic and socio-cultural changes that could be observed as early as the 19th century, the article analyses the factors that led to an extreme formal reduction in church decoration. Apart from the obvious issue of interior architecture, a reflection is undertaken on the way in which art, which is both a cult and an aesthetic element, is displayed. Legal factors, liturgical and psychological aspects are also taken into account. To analyse the problem, realisations and projects from the circle of European architecture have been used.

Keywords: interior design; aesthetics; design; art of the Roman Catholic Church; sacred interior; church architecture; minimalism
\end{abstract}

